J. Perinat. Med. 17 (1989) 417

\title{
Placental lipid contents in preterm labor complicated by chorioam- nionitis
}

\author{
Josip Delmis
}

Department of Obstetrics and Gynecology, Medical School, University of Zagreb, Yugoslavia

\section{Introduction}

Premature labor complicates $8-10 \%$ pregnancies, making it one of the more common and serious problems in obstetrics [6]. The perinatal morbidity and mortality associated with prematurity make this complication all the more significant. It has been estimated that $85 \%$ of perinatal deaths not due to congenital anomalies occur in premature infants [13]. Despite the identification of multiple risk factors for premature labor, no clear-cut etiologic mechanism can be identified in the majoritty of patients who deliver prematurely. Recent studies have suggested that preterm labor and delivery may be associated with intrauterine infection [12]. Microorganisms from the vaginal flora might be a source of phospholipase A2, (PLA2) which can induce the release of arachidonic acid, (AA), leading to prostaglandin production [1]. These investigators have postulated that bacterial products directly stimulate the biosynthesis of prostaglandins by the amnion and the decidua. Several authors [7, 10] have demonstrated elevated concentration of AA prostaglandin (PG) E2, PGF2a, 5-hydroxyeicosatetraenoic acid (5-HETE), 15-hydroxyeicosatetraenoic acid (15-HETE), and leukotriene B4 in the amniotic fluid of women with preterm labor and intraamniotic infection [10]. A number of these products can stimulate myometral contractions in a dose-dependent manner [2]. Other investigators have demonstrated elevated concentrations of $\mathrm{AA}$ and prostaglandins in the membranes [4, 14] and decidua [9] of patients with preterm labor.

Substances that stimulate labor must reach the myometrium (presumably via the placenta) in

\section{Curriculum vitae}

Josip DeLmis, M.D., Dr.Sc., was born on April 18, 1947 in Subotica, Yugoslavia. From 1966-1971 he studied medicine at the University of Zagreb and received his doctoral degree in 1971. He spent one year at the Brown University, Providence, Rhode Island, USA and was a resident at the Department of Obstetrics \& Gynecology in Zagreb. His main scientific interests include perinatology and biochemistry.

order to exert their effect. The present study was designed to investigate the effect of chorioamnionitis on the content of $\mathrm{AA}$ in decidua-free placental fissue.

\section{Material and methods}

Fifteen placentals from preterm deliveries were analyzed. Group I consisted of nine preterm deliveries without evidence of chorioamnionitis, in which no tocolysis had been administered. Group 2 consisted of 6 preterm deliveries with evidence of chorioamnionitis. In order to be included in this group, membranes had to have been ruptured at least 24 hours prior to delivery, and at least 2 of the following clinical signs had to be present: fever $>38^{\circ} \mathrm{C}$, uterine tenderness, foul-smelling vaginal discharge and leukocytosis (counts greater than 18,000 per cubic milimeter). 
In addition, histologic evidence of severe amnionitis was present in these six placentas.

Gestational ages were calculated from the first day of the last menstrual period which was known in every case.

The placentae were cooled and washed immediately after delivery with Lactated Ringers' solution at less than $4{ }^{\circ} \mathrm{C}$. Decidua was cut away from the cotyledons and villous tissue was obtained from multiple cotyledons. The tissue was teased of blood vessels and minced into fine pieces. The tissue was rinset three to four times in ice cold Lactated Ringer's solution to remove residual blood, and immediately frozen at $-4^{\circ} \mathrm{C}$ or at $70^{\circ} \mathrm{C}$, respectively. Two placental tissues, which belonged the group I were stored at $-4{ }^{\circ} \mathrm{C}$ (in the beginning of our study) until extraction. The time which elapsed between harvest and extraction was $6.6+3.4$ days, in the group of preterm labor and $7.8+4.3$ days in the group of preterm labor complicated with chorioamnionitis.

Extraction of lipids was performed as follows: Placental tissue $(14-16 \mathrm{mg}$ ) was suspended in $1 \mathrm{~mL}$ of distilled water and homogenized in a Potter-Elvejehm glass homogenizer then lipid was extracted with water: chloroform:methanol $(2: 1: 1)$. Substituted forms of heptadecanoic acid $(17: 0)$ were added as internal standards to quantitate the phospholipids (PL), free fatty acids (FFA), triglycerides (TG), and cholesterol esters (CE). The extract was dried unter a stream of nitrogen, and the lipids were redissolved in $0.1 \mathrm{~mL}$ of chloroform/methanol $(2 / 1, \mathrm{v} / \mathrm{v})$. Thinlayer chromatography was performed on silicic acid-impregnated paper (Gelman Instrument Co., Ann Arbor, Michigan). The developing solvent for thin-layer chromatography was petroleum ether/diethylether/acetic acid (90/10/1). The thin-layer chromatography papers were developed with $0.1 \%$ dichlorofluorescein solution, and the bands of lipids were visible under ultraviolet light. The phospholipids, nonesterified fatty acids, triglycerides, and cholesterol esters appeared as distinct bands which were then cut apart and put into Teflon-lined screw-capped glass tubes. These were esterified with boron brifluoride-methanol at $75^{\circ} \mathrm{C}$ for one hour. After esterification, the lipids were extracted with petroleum ether three times to ensure quantitative transfer. The samples were taken to dryness under nitrogen at room temperature and redis- solved in a small amount of petroleum ether for gas-liquid chromatographic analysis. Gas-liquid chromatography of the fatty acid methyl esters was carried out on a Packard Model 439A Gas Chromatograph (Packard Instrument Co., Inc., Downers Grove, Illinois). The columns used for GLC are Quadrex fused silica glass capillary column (007 FFAP-liquid phase). This procedure allowed separation of methyl esters of fatty acids from eight carbons to 22 carbons. Peak areas were measured by electronic digital integrator (Spectra Physics SP 4200-Computing Integrator). Quantification of fatty acids was accomplished by injection of a known amount of methyl heptadecanoate in comparison with the internal standard in each sample. Identification of fatty acid methyl esters was made by comparison with known methyl ester standards.

Results were tested for significance by the twotailed Student's $t$ test, with $\mathrm{p}<0.05$ providing evidence for significant differences. The correlation between proportion of arachidonic acid in lipid groups and gestational age were assessed with linear regression and in $2 \times 2$ tables, for which significance was determined by two-tailed Fisher's exact test.

\section{Results}

Demographic data from the two groups are shown in table I: Statistical analysis has shown that there is no statistically significant difference between the two groups in maternal age and harvest-extraction intervals. The mean gestational age and the mean birthweight were lower in the group of preterm deliveries complicated with chorioamnionitis.

None of the mothers had hypertensive disorders of pregnancy, diabetes mellitus or $\mathrm{Rh}$ isoimunisation. None of the infants had any detectable congenital anomalies. All babies were delivered vaginally.

Table II compares lipid patterns in the two groups. Although there appears to be a trend toward higher total lipids, total phospholipids and total free fatty acids in the placentas of pregnancies complicated by chorioamnionitis, these apparent differences were not statistically significant. There was a highly significant increase in placental arachidonic acid content, arachidonic acid in phospholipids, and arachidonic 
Table I. Demographic data from the two groups patients

\begin{tabular}{lccc}
\hline Group & $\begin{array}{l}\text { Preterm labor } \\
\text { (Mean } \pm \text { SD) }\end{array}$ & $\begin{array}{l}\text { Preterm Labor }+ \\
\text { chorioamnionitis }\end{array}$ & (p) \\
\hline $\begin{array}{l}\text { Maternal age } \\
\text { (years) }\end{array}$ & $25.8 \pm 3.9$ & $27.7 \pm 4.6$ & $\mathrm{NS}$ \\
$\begin{array}{l}\text { Gestational age } \\
\text { (weeks) }\end{array}$ & $34.2 \pm 2.5$ & $28.3 \pm 2.0$ & $\mathrm{p}<0.05$ \\
$\begin{array}{l}\text { Birth weight } \\
\text { (grams) }\end{array}$ & $2510.0 \pm 508.8$ & $1386.7 \pm 843.4$ & $\mathrm{p}<0.05$ \\
$\begin{array}{l}\text { Harvest-extraction interval } \\
\text { (days) }\end{array}$ & $6.6 \pm 3.4$ & $7.8 \pm 4.3$ & $\mathrm{NS}$ \\
\hline
\end{tabular}

Table II. Arachidonic acid patterns in placental tissue

\begin{tabular}{llll}
\hline Measurement & $\begin{array}{l}\text { Preterm } \\
\text { deliveries } \\
\text { (ug/g placental tissue) }\end{array}$ & $\begin{array}{l}\text { Preterm } \\
\text { deliveries }+ \text { chorioamnionitis }\end{array}$ & $\begin{array}{l}\text { Statistical } \\
\text { significance }\end{array}$ \\
\cline { 2 - 4 } & (Mean \pm SD) & (Mean \pm SD) & \\
\hline total lipids & $4645.8 \pm 804.7$ & $5430.6 \pm 769.2$ & $\mathrm{NS}$ \\
total AA & $784.1 \pm 113.2$ & $1297.2 \pm 181.0$ & $\mathrm{p}<0.05$ \\
total PL & $3328.6 \pm 558.6$ & $4013.9 \pm 412.0$ & $\mathrm{NS}$ \\
AA in PL & $655.8 \pm 130.1$ & $1027.1 \pm 137.3$ & $\mathrm{p}<0.05$ \\
total FFA & $349.5 \pm 117.1$ & $697.5 \pm 369.8$ & $\mathrm{NS}$ \\
AA in FFA & $61.8 \pm 16.4$ & $168.2 \pm 63.1$ & $\mathrm{P}<0.05$ \\
total TG & $534.8 \pm 620.3$ & $334.7 \pm 53.7$ & $\mathrm{NS}$ \\
AA in TG & $39.1 \pm 36.4$ & $88.4 \pm 53.7$ & $\mathrm{NS}$ \\
total Ce & $432.9 \pm 381.1$ & $156.5 \pm 132.8$ & $\mathrm{NS}$ \\
AA in CE & $27.4 \pm 37.5$ & $13.5 \pm 7.5$ & $\mathrm{NS}$ \\
\hline
\end{tabular}

Total $\mathrm{AA}=$ total arachidonic acid. Total $\mathrm{PL}=$ total phospholipids. $\mathrm{AA}$ in PL $=$ content of arachidonic acid in phospholipids. AA in FFA = content of arachidonic acid in free fatty acids. Total TG $=$ total triglycerides. $\mathrm{AA}$ in TG = Arachidonic acid in triglycerides. Total $\mathrm{CE}=$ total cholesterol esters. $\mathrm{AA}$ in $\mathrm{CE}=$ Arachidonic acid in cholesterol esters.

Table III. Proportion of AA in the lipids groups

\begin{tabular}{llll}
\hline Measurement & $\begin{array}{l}\text { Preterm } \\
\text { deliveries }\end{array}$ & $\begin{array}{l}\text { Preterm } \\
\text { deliveries }+ \\
\text { chorioamniotis } \\
\text { (Mean } \pm \text { SD) }\end{array}$ & $\begin{array}{l}\text { Statistical } \\
\text { significance }\end{array}$ \\
\hline \% PL AA & $20.0 \pm 3.8$ & $25.9 \pm 4.7$ & (p) \\
\% FFA AA & $18.0 \pm 2.9$ & $25.6 \pm 7.0$ & $\mathrm{p}<0.05$ \\
\% TG AA & $8.9 \pm 4.3$ & $24.3 \pm 14.0$ & $\mathrm{NS}$ \\
\% CE AA & $9.0 \pm 13.0$ & $8.6 \pm 0.5$ & $\mathrm{p}<0.05$ \\
\% Total lipid AA & $17.4 \pm 4.7$ & $24.0 \pm 2.8$ & $\mathrm{NS}<0.05$ \\
\hline
\end{tabular}

$\%$ PL AA $=$ Percent of phospholipids made up of arachidonic acid. \% FFA AA = Percent of free fatty acids made up of arachidonic acid. \% TG AA = Percent of triglycerides made up of arachidonic acid. \% CE AA $=$ Percent of cholesterol esters made up of arachidonic acid. \% Total lipid AA = Percent of total lipid made up of arachidonic acid. 
acid in free fatty acid in placentas from pregnancies with chorioamnionitis.

Table III depicts the proportion of each lipid category comprised of arachidonic acid. Arachidonic acid made up a significantly higher proportion of phospholipids and triglycerides in placental tissue from preterm pregnancies complicated by chorioamnionitis, while the proportions of free fatty acids and cholesterol esters were not significantly different. Arachidonic acid also made up a significantly higher proportion of total lipids in these placentae.

Figure 1 depicts the regression of arachidonic acid in phospholipids on gestational age. The correlation coefficient of $0.06(p>0.05)$ suggests that the difference in gestational age is not responsible for the effect of chorioamnionitis. Similarly poor correlation was found between gestational age and the proportion of arachidonic acid in total lipids, free fatty acids, triglycerides and cholesterol esters.

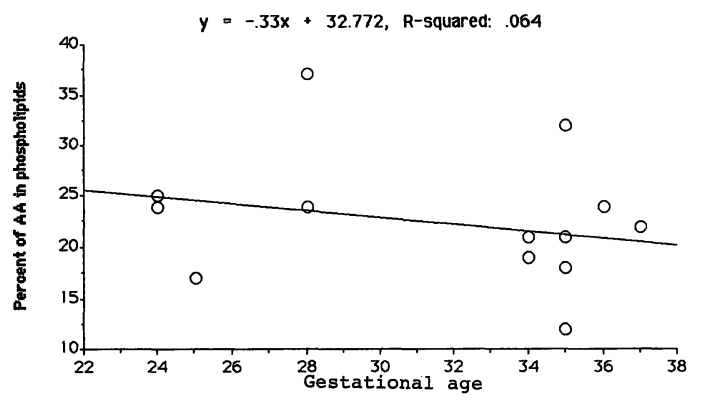

Figure 1. Regression between gestational age and proportion of $\mathrm{AA}$ in phospholipids.

\section{Discussion}

The data above reveal that arachidonic acid is present in significantly increased amounts in the placentas of women with chorioamnionitis and preterm delivery, as compared to those of women with preterm delivery in the absence of chorioamnionitis. Other investigators have demonstrated increased arachidonic acid levels in decidua, membranes and amniotic fluid of such patients. Our data would suggest that arachidonic acid released from amnion and decidua may be taken up by the placenta and thus enter the fetal bloodstream. Alternatively, the placenta itself represents a possible production and stor- age depot for prostaglandin precursors, which may be mobilized by various stimuli in cases of intrauterine infection.

During normal pregnancy, serum concentrations of free fatty acids increase with each trimester and increase to even greater levels during labor [8]. The serum concentration of arachidonic acid in free form are elevated at the time of labor. However, the percentage of total free fatty acids consisting of arachidonic acid is decreased during labor [8]. It should be noted that the precentage of free fatty acids consisting of arachidonic acid is much higher in cord blood than in maternal blood [8]. This difference is consistent with the hypothesis that the fetus and placenta may be an important source of arachidonic acid used for prostaglandins production during labor.

In our study, there was a statistically significant difference in gestational ages in the two groups. The mean gestational age in the group of the preterm labor was higher than in the group of preterm labor complicated with chorioamnionitis. However, we found no correlation between gestational age and total lipids, as well as gestational age and the proportion of arachidonic acid in phospholipids, free fatty acid, triglycerides and cholesterol esters. Thus it is unlikely that the gestational age differences account for the effect observed.

Prostaglandins are key mediators for labor. During spontaneous term and preterm labor, levels of prostaglandins E2 and F2a in the amniotic fluid and fetal blood increase, reaching their highest values at the time of full dilation of the cervix $[3,5]$. Nonesterified arachidonic acid is the obligate precursor of PGF2a and PGE2. Phospholipase A2 has been shown to be an important enzyme for releasing polyunsaturated fatty acids needed in prostaglandin synthesis. Arachidonic acid [7] increases in amniotic fluid during spontaneous labor, and the injection of arachidonic acid intraamniotically can induce abortion or labor.

Microorganisms ascending from the vaginal flora are a likely source of phospholipase A2, which may induce the release of arachidonic acid. ROMERo et al (1987) found endotoxin or lypopolysaccharide to be present in the amniotic fluid of gravidae with chorioamnionitis [11]. Since endotoxin is capable of stimulating prostaglandin production by several cell types (e.g. macrophages), these authors postulated that such a 
bacterial product could stimulate $P G$ production by the intrauterine contents, stimulating labor. Indeed, endotoxin can stimulate PGE2 production by human amnion and decidua, and the incubation of human amnion with several bacterial products has been shown to stimulate PG production [10]. Whether these labor-stimulating products are produced exclusively in the decidua, and traverse the placenta on the way to the myometrium, or the placental substance itself is capable of their prodtuction, remains an open question.

\begin{abstract}
Fifteen decidua free placental samples from nine preterm deliveries without evidence of chorioamnionitis and six preterm deliveries with evidence of chorioamnionitis were analyzed for fatty acids contents. The percentage of arachidonic acid in phospholipids, in free fatty acids, in triglycerides and cholesterol esters
\end{abstract}

were also measured in each sample. Arachidonic acid was found to be present in significantly increased amounts in the placentas of women with chorioamnionitis and preterm delivery, as compared to those of women with preterm delivery and the absence of chorioamnionitis.

Keywords: Arachidonic acid, chorioamnionitis, preterm delivery.

\section{Zusammenfassung}

\section{Lipidgehalt in der Plazenta bei Frühgeburt und Chorio-} amnionitis

Neuere Studien von Romero et al. [3] haben gezeigt, da $\beta$ vorzeitige Wehen und Frühgeburt mit einer intrauterinen Infektion einhergehen können. Mikroorganismen aus der Vaginalflora liefern Phospholipase $A_{2}$, welche Arachidonsäure (AA) freisetzt. Dies wiederum führt zur Produktion von Prostaglandin, was BeFAR et al. zeigen konnten [4].

In der vorliegenden Studie wollten wir die Auswirkungen einer Chorioamnionitis auf den Gehalt an AA in deziduafreiem Plazentagewebe untersuchen. Gruppe 1 bestand aus 15, nicht mit Dezidua kontaminierten Plazentaproben von 9 Frühgeburten ohne Chorioamnionitis, in denen wir die Menge von freien Fettsäuren bestimmten. In Gruppe 2 waren Proben von 6 Frühgeburten mit Zeichen einer Chorioamnionitis. Der Blasensprung mußte mindestens $24 \mathrm{~h}$ ante partum erfolgt sein und mindestens zwei der folgenden Symptome sollten nachweisbar sein: Fieber höher als $38^{\circ} \mathrm{C}$, weicher Uterus, übelriechender, vaginaler Fluor und Leukozytose.
Die Extraktion der Lipide aus dem Plazentagewebe erfolgte dünnschichtchromatographisch auf silikatimprägniertem Papier (Gelman Instrument, Co., Ann Arbor, Mich.). Mit dieser Methode konnten Methylester von Fettsäuren mit von 8 bis 22 C-Atomen getrennt werden. Die Fläche unter den Peaks wurde elektronisch ausgewertet.

Die Ergebnisse wurden im Student's-Test auf ihre Signifikanz überprüft, wobei ein $p<0,05$ für signifikante Unterschiede galt. Mit Regressionsgeraden und in $2 \times 2$-Tabellen wurde die Korrelation zwischen AAAnteil in Lipidverbindungen und Gestationsalter geprüft; die Signifikanz wurde im Fischer-Test ermittelt. Tabelle I zeigt die demographischen Daten der beiden Gruppen; es fanden sich keine signifikanten Unterschiede. Tabelle II vergleicht die Lipidmuster der Gruppen. Bei Plazenten aus Schwangerschaften mit Chorioamnionitis fand sich ein signifikanter Anstieg des AAGehaltes in der Plazenta $(1297 \pm 181 ; t=5,13$; $\mathrm{p}=0,0032)$, in den Phospholipiden $(1027 \pm 137,3$; $\mathrm{t}=4,48 ; \mathrm{p}=0.0065$ ) und in freien Fettsäuren $(168,2 \pm 63,1 ; \mathrm{t}=4,24 ; \mathrm{p}=0,0082)$.

Schlüsselwörter: Akute Chorioamnionitis, Arachidonsäure, Frühgeburt.

\section{Résumé}

Teneur lipidique placentaire au cours de l'accouchement prématuré compliqué de chorioamniotite

Des études récentes de Romero et coll. [3] ont suggéré que le déclenchement prématuré du travail et l'accouchement peuvent s'accompagner d'une infection intrautérine. Certains microorganismes de la flore vaginale peuvent être une source de phospholipase $A_{2}$, qui peut induire la libération d'acide arachidonique (AA) amenant à la production de prostaglandine repportée par BEJAR et coll. [4].
Le but de cette étude a été d'explorer d'effet de la chorioamniotite sur la teneur en AA de fragments placentaires sans decidua. Quinze échantillons placentaires sans decidua provenant de neur placentas de prématurés sans chorioamniotite ont été analysés quant à leur teneur en acides gras libres, ces échantillons formaient le groupe 1 . Le groupe 2 correspondait à 6 placentas de prématurés avec chorioamniotite. Pour l'inclusion dans ce groupe, les membranes devaient être rompues au moins 24 heures avant l'accou- 
chement, et au moins 2 des signes cliniques suivants devaient être présents: fièvre $>38^{\circ} \mathrm{c}$, sensibilité utérine, pertes vaginales malodorantes et hyperleucocytose.

L'extraction lipidique des fragments placentaires étaient effectuée par chromatographie en couche mince sur du papier imbidé d'acide silicique (Gelman instrument, Co., Ann Arbor, Mich.). Cette technique permet la séparation des esthers méthylés des acides gras de 8 à 22 carbones. Les aires des pics ont été mesurées par un integrateur digital électronique.

La signification des tests a été étudiée par des tests $\mathbf{t}$ de student, un $\mathrm{p}<0,05$ prouvant des différences significatives. La corrélation entre la proportion d'AA dans les ensembles lipidiques et l'âge gestationel a été appréciée par régression linéaire et par des tables de $\mathrm{X}_{2}$, pour lesquelles la signification était déterminés par test de Fisher.

Les données démographiques concernant les deux groupes figurent sur le tableau I et il n'a pas été trouvé de différences significatives. Le tableau II compare les lipides des deux groupes Dans les placentas provenant des grossesses avec chorioamniotite il y a une élévation très significative de la teneur placentaire en AA (1297 $\pm 191 ; \mathrm{t}=5,13 ; \mathrm{p}=0,0032)$, de l'AA des phospholipides $(1027 \pm 137,3 ; t=4,48 ; p=0,0065)$ et de l'AA des acides gras libres $(168,2 \pm 63,1 ; \mathrm{t}=4,24$; $\mathrm{p}=0,0082$ ).

Le tableau III montre clairement que l'AA représente une proportion significativement plus élevées des phospholipides et des triglycérides dans les fragments placentaires des prématurés.

Les données de cette étude révèlent que l'AA est en quantité significativement augmentée dans les placentas des femmes présentant une chorioamniotite et un accouchement prématuré en comparaison de ceux des femmes avec accouchement prématuré sans chorioamniotite. Nos données suggèrent que l'AA libérée par l'amnios et la decidura est capté par le placenta et ainsi pénètre dans la circulation fotale ou bien que le placenta luimême représente un site possible de production et de stockage des précurseurs des prostaglandines qui peuvent être mobilisés par divers stimuli en cas d'infection intra-utérine.

Mots-clés: Accouchement prématuré, acide arachidonique, chorioamniotite aigüe.

\section{References}

[1] Bejar R, U Curbelo, C Davis, L Gluck: Premature labor: II. Bacterial sources of phospholipase Obstet. Gynecol 57 (1981) 479

[2] BENET PR, MG Elder, L MyATt: The effects of lipoxygenase metabolites of A on human myometral contractility. Prostaglandins 44 (1987) 837

[3] Chalis JRG, JE Patrick: The production of prostaglandin and tromboxanes in the feto-placental unit and their effects on the developing fetus, semin Perinatol 4 (1980) 23

[4] Curbelo U, R Bejar, K BenirschKe, L Gluck: Premature labor I. Prostaglandin precursors in human placental membranes. Obstet Gynecol 57 (1981) 473

[5] Delmis J, M Iuanisevic, A Drazancic, M ArAMBASIN: Prostaglandins in feto-placental circulation. Jugoslav ginekol perinatol 27 (1987) 137

[6] Dodson MG, SJ Fortunato: Microorganisms and Premature labor. J Reprod Med 33 (1988) 87

[7] MacDonald PC, FM Schultz, JH Duenhalter, NF GaNt, JM Jimenez, JA PRITCHARD, JC PoRTER, JM JOHNSTON: Initiation of human parturition. I. Mechanism of action of arachidonic acid 44 (1974) 629

[8] Ogbourn PL, WE Brenner: Possible role of arachidonic acid in labor. In: OGBOURN PL, WE BRENNER (eds): The physiologic actions and effects of prostaglandins. Current concepts, Upjohn 198115

[9] OKaZAKI T, N Sagana, BleusheK et al: Initiation of human parturition: XIII. Phospholipase C, phospholipase A2, and diacylglycerol lipase activ- ities in fetal membranes and dexidua vera tissues from early and late gestation Biol Reprod 25 (1981) 103

[10] Romero R, M Emamiam, M Wan, R Quintero, JC HobBins, MD Mitchell: Prostaglandin concentration in amniotic fluid of women with intraamniotic infection and preterm labor, Am J Obstet Gynecol 157 (1987) 1461

[11] ROMERo R, N KADAR, JC HobBIns et al: Infection and labor: The detection of endotoxin in amniotic fluid. Am J Obstet Gynecol 157 (1987) 815

[12] Romero R, M Mazor, KY WU, M Sirtori, E OYARZUM, MD MITCHELl, JC HOBBINS: Infection in the pathogenesis of preterm labor. Semin Perinatol 12 (1988) 262

[13] Rush RW, MJNG KeIRSe, P Horvat et al: Contribution of preterm delivery to perinatal mortality. Br Med J 2 (1976) 965

[14] Schwarz BE, FM Schultz, PC MacDonald et al: Initiation of human parturition: III. Fetal membrane content of prostaglandin E2 and F2a precursor. Obstet Gynecol 46 (1985) 564

Received April 11, 1989. Accepted October 16, 1989.

Josip Delmis, M. D., Dr. Sc.

Department of Obstetrics and Gynecology

Medical School, University of Zagreb

Petrova 13

41000 Zagreb

Yugoslavia 